BIOKEMISTRI 18(1):15-20 (June 2006)

Available online at http://www.bioline.org.br/bk

and at http://www.aiol.info/journals/biokem

Printed in Nigeria

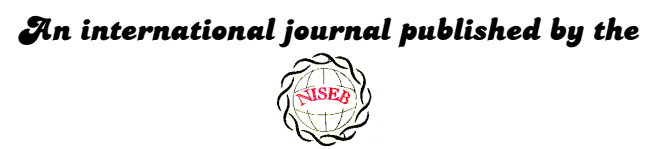

OVigerian Society for O̊xperimental ßiology

\title{
Comparison of $\alpha$-amylase activity in some sprouting Nigerian cereals
}

\author{
Evans C. EGWIM* and Oyelola B. OLOYEDE \\ Department of Biochemistry, University of Ilorin, PMB 1515, Ilorin, Kwara State, Nigeria
}

Received 16 November 2004

MS/No BKM/2004/034, ( 2006 Nigerian Society for Experimental Biology. All rights reserved.

\begin{abstract}
The yield and characteristics of Alpha-amylase obtained from some sprouting Nigeria cereals (maize, acha, rice and sorghum) were compared using standard procedures. The result indicated maximum $\alpha$-amylase yield was attained from 72-120 hours of sprouting cereals). Of all the sprouted cereals, acha gave rise to the highest amylase yield $\left(16.6 \pm 0.02 \times 10^{2}\right.$ and the least was exhibited by maize $\left(11.0 \pm 0.04 \times 10^{2}\right)$. The optimum temperature for $\alpha$-amylase activity was $60^{\circ} \mathrm{C}$ for maize and rice while that of acha and sorghum was $70^{\circ} \mathrm{C}$. The optimal pH for the activity of $\alpha$-amylase from sprouting maize, rice, acha, and sorghum were exhibited at 6.5, 5.5, 6.5 and 5.8 respectively. The apparent kinetic parameters, $\mathrm{V}_{\max }$ and $\mathrm{K}_{\mathrm{m}}$, were $9.0 \times 10^{-2}$ and $0.23 ; 12.5 \times 10^{-2}$ and $0.56 ; 7.0 \times 10^{-2}$ and $0.29 ; 12.5 \times 10^{-2}$ and 0.50 for $\alpha$-amylase from sprouting maize, acha, rice and sorghum respectively. It is concluded that $\alpha$-amylase obtained from sprouting Nigeria cereals manifest differences in quality and quantity, and may be useful in different starch processing industries.
\end{abstract}

Key words: cereals, $\alpha$-amylase, sprouting, apparent kinetics, acha

*Author to whom correspondence should be addressed at current address: Science Laboratory Technology Department, Federal Polytechnic, PMB 55, Bida, Niger State, Nigeria. E-mail: evansegwim@yahoo.com; Tel: 08036832178 


\section{INTRODUCTION}

Classical $\alpha$-amylases catalyses the hydrolysis of $\alpha$-1,4-glucosidic linkages in starch, and different amylases give rise to oligosaccharides with specific lengths of glucose as major products $^{1}$, for this reason, different types of amylases, with unique properties are isolated and characterized for various applications in the starch industry ${ }^{2}$.

Amylase obtained from cereals during malting is the main enzyme employed in enzymatic saccharification of starch in most starch-based industries in Nigeria. Such industries include breweries, pharmaceuticals, distilleries etc.. The major cereals employed in Nigerian industries are maize, sorghum and millet. Okafor et al ${ }^{3}$ have shown however that maize, sorghum and millet have poor malting quality. This results in low yield of amylase and consequently a low yield of fermentable sugars. Barley and wheat are most popular sources of cereal amylase employed in the food industries. It is estimated that about $10.4 \%$ of barley produced world wide is used in malt and enzyme production for the brewery and confectionery industry ${ }^{4}$. The cultivation of barley in Nigeria has however met with little success. As such, huge amount of foreign exchange was spent annually in importing barley malt before the ban. Industrialists have therefore resorted to importation of microbial amylases for starch hydrolysis. However, present realities show that local resources can be used effectively for malt and enzyme production. The common cereals include maize, rice, sorghum, acha and millet. Earlier studies have shown sorghum to be the most suitable ${ }^{5}$. Other local and unpopular cereals may also be a close alternative. The present study is designed to compare the yield, activity optimal and apparent kinetic parameters of alpha amylase from sprouting maize (Zea mays), Acha (Digitaria exilis), Rice (Oryza satva) and Sorghum (Sorghum bicolor)

\section{MATERIALS AND METHODS}

\section{Chemicals}

All chemicals used for the present work were of analytical grade (Analar) being products of
British Drug House (BDH) Chemical Limited pole, England.

\section{Cereals}

Maize, Acha, Rice and Sorghum were obtained from National Cereals Research Institute (NCRI) Badeggi, Niger State, Nigeria.

\section{Determination of germination capacity}

Cereals viability test was carried out following the procedure described by Vontong and Venone ${ }^{6}$. Seeds were selected at random; cleaned and unfilled seeds were discarded. 100 grains of cereal were counted and weighed. The grains were washed with detergents and rinsed 4 times with distilled water. The grains were steeped for 24 hours in water, the water was drained and the grains evenly distributed in a compact single layer on Petri dishes over laid with moistened filter paper. The Petri dishes were covered and placed in the dark at room temperature for germination. Moisture content was maintained by occasionally adding drops of water to the filter paper. After 72 hours, seeds having shoot longer than $1 \mathrm{~cm}$ were considered to be viable. Viable seeds were counted and presented as percentage viable seed.

\section{Determination of alpha- amylase yield in sprouting cereals}

$500 \mathrm{~g}$ of each cereal was cleaned and sprouted as described earlier. Samples were withdrawn from each sprouting cereal at $12 \mathrm{hrs}$ intervals up to 180 hours. $1 \mathrm{~g}$ of sprouting cereal was milled in $5 \mathrm{ml}$ of pre chilled $0.05 \mathrm{M}$ citrate buffer, $\mathrm{pH} 6.0$; the resulting homogenate was centrifuged at $10,000 x g$ for 10 minutes. Enzyme activity was assayed in the supernatant as yield of crude enzyme.

\section{Assay of Enzyme Activity}

Alpha amylase activity was assayed by a modification of the method described by Kang et $a l^{7} .0 .1 \mathrm{ml}$ of supernatant (Crude enzyme) was pipetted into a separate test tube and $0.9 \mathrm{ml}$ of $2 \%$ soluble starch was added and incubated in a shaking water bath at $50^{\circ} \mathrm{C}$ for 30 minutes. The reaction was stopped by adding DNSA (Dinitrosalicylic acid) reagent and boiled for at least 3 minutes for colour development. Absorbance was read at $550 \mathrm{~nm}$ against blank. The blank contained all the assay reagents without the 
enzyme. Standard glucose curve was prepared from glucose concentrations of 0.0, 0.2, 0.4, 0.6, 0.8 and $1.0 \mathrm{mg} / \mathrm{ml}$.

\section{Determination of $\mathrm{pH}$ and Temperature optima}

Optima $\mathrm{pH}$ and temperature of activity of the different cereal alpha amylase were determined following the methods described by Shambe et $a l^{5}$. Crude enzyme was produced as described above in citrate buffers of $\mathrm{pH} 3.0,3.5,4.0,4.5$, 5.0, 5.5, 6.0, 6.5, 7.0 and 7.5; enzyme activity was assayed at constant temperature. For optimum temperature, enzyme assay mixture was incubated at temperatures of $20^{\circ} \mathrm{C}, 30^{\circ} \mathrm{C}$, $40^{\circ} \mathrm{C}, 50^{\circ} \mathrm{C}, 60^{\circ} \mathrm{C}, 70^{\circ} \mathrm{C}$ and $80^{\circ} \mathrm{C}$ for 30 minutes at constant $\mathrm{pH}$

\section{Kinetic parameters}

Kinetic parameters $\left(\mathrm{V}_{\mathrm{Max}}\right.$ and $\left.\mathrm{K}_{\mathrm{M}}\right)$ were determined from Hanes Plot of $[\mathrm{s}] /$ vo vs [s], Slop $=1 / \mathrm{V}_{\text {Max }}$. The Intercept on the $\mathrm{Y}$ axis= $\mathrm{K}_{\mathrm{M}} / \mathrm{V}_{\mathrm{Max}}$

\section{Enzyme activity}

Enzyme activity in the present work is defined as the amount of enzyme required to liberate a unit of glucose per minute ( $\mathrm{mg}$ glucose $/ \mathrm{ml} / \mathrm{min}$ ) at reaction conditions.

\section{RESULTS AND DISCUSSIONS}

Germination capacity (viability) of the cereals studied is shows Table 1 . The germination capacity was highest for acha and sorghum and lowest for maize. The germination capacities of all the seeds studied were within the recommended range. Votong and Vonone ${ }^{6}$ have shown that cereal germination capacity of up to $80 \%$ was recommended as viable

Table 1: Germination Capacity (\%)

\begin{tabular}{|l|l|}
\hline Cereals & $\%$ Germination \\
\hline Maize & $96 \pm 0.06$ \\
Acha & $98 \pm 0.02$ \\
Rice & $98 \pm 0.08$ \\
Sorghum & $97 \pm 0.06$ \\
\hline
\end{tabular}

Amylase yield in sprouting cereals is shown in Figure 1. Sprouting acha showed maximum amylase activity from $72-120 \mathrm{hrs}$ with a peak at 96 hours. Sprouting maize and rice showed peak amylase activity at 72 hours while sorghum amylase was at 84 hours.

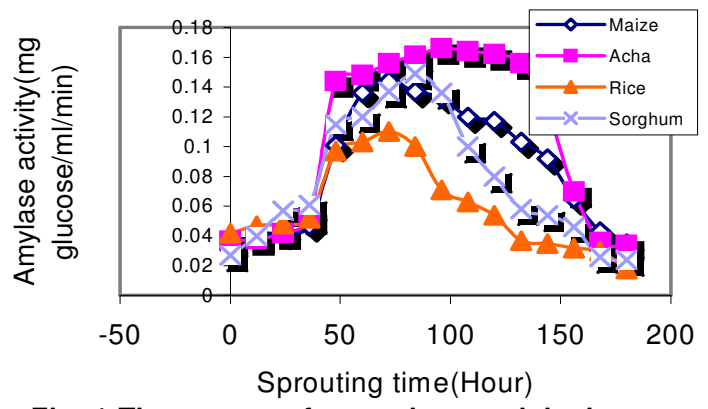

Fig. 1 Time course for amylase activity in sprouting cereals

The present observation showed that acha must be sprouted 96 hours, maize, and rice for up to 72 hours while sorghum must be sprouted for up to 84 hours for maximum amylase production. At the peak amylase production, the amylase activities were $16.6 \pm 0.02 \times 10^{-2}, 14.4 \pm 0.06 \mathrm{X}$ $10^{-2}, 11.0 \pm 0.04 \times 10^{-2}$ and $14.9 \pm 0.09 \times 10^{-2}$ $\mathrm{mg}$ glucose per minute for sprouting acha, maize, rice and sorghum respectively. The present result showed that acha has the highest yield of alpha amylase at peak amylase production while rice has the lowest. This observation shows that acha may be superior to maize, rice and sorghum in terms of alpha amylase yield at peak amylase production.

The effect of temperature on sprouting cereals alpha amylase activity is shown in Fig. 2.

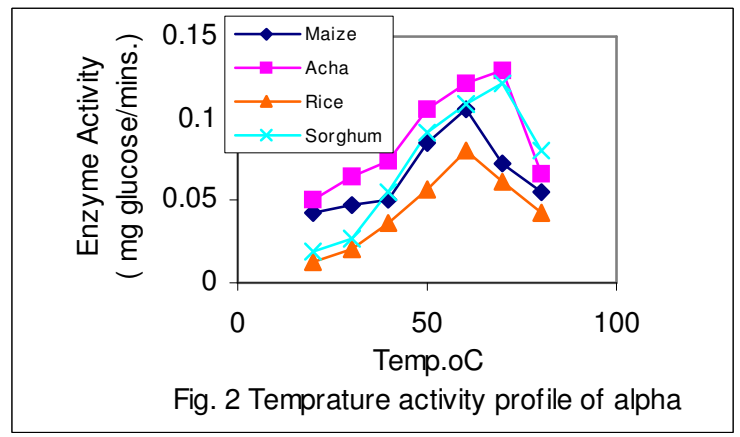

The result shows an optimum temperature of $60^{\circ} \mathrm{C}$ for alpha amylase from sprouting 


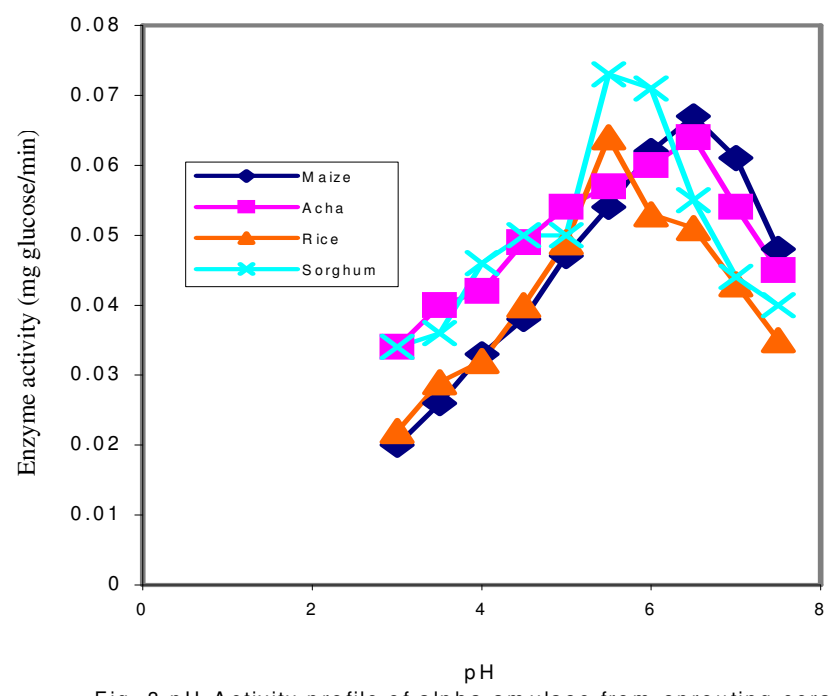

Fig. 3: pH-Activity profile of alpha-amylase from sprouting cereal

maize and rice and $70^{\circ} \mathrm{C}$ for acha and sorghum amylase. The present observation suggests that acha and sorghum amylase may be closely related physiologically. The optimum temperature observed for maize amylase agrees with that reported by Olatunji and Ene $^{8}$ while Francis and Folorunsho ${ }^{9}$ have reported an optimum temperature of $70^{\circ} \mathrm{C}$ for $\alpha$-amylase in fermenting cassava vessel. It is obvious that $\alpha$-amylase from different sources have different temperature optimal for different applications. From the present study it implies that starch-hydrolysing industries that run at lower temperatures may find the maize and rice $\alpha$-amylase useful while processes that require higher temperature will prefer acha and sorghum $\alpha$-amylase. The present observation further suggests that $\alpha$-amylase from the cereals in this study have different characteristics.

The $\mathrm{pH}$ profile is shown in Fig 3. The optimal $\mathrm{pH}$ for the activity of $\alpha$-amylase from sprouting maize, rice acha and sorghum are 6.5, 5.5, 6.5 and 5.8 respectively. Alli et $a l^{10}$ have reported a $\mathrm{pH}$ optimum of 4.0-6.0 for crude fungal $\alpha$ amylase in the hydrolysis of selected Nigerian cereal starches while Olatunji and
Ene $^{8}$ obtained $\mathrm{pH}$ values of 6.5 and 6.8 for bacteria $\alpha$-amylase during the hydrolysis of maize and potato starches respectively. It implies therefore that $\alpha$-amylase from sprouting Nigerian cereals may be employed in starch hydrolysis. It should be noted that optimum $\mathrm{pH}$ indicates the $\mathrm{pH}$ at which the maximum number of active sites are available for reactivity.

The effect of substrate (starch) concentration on $\alpha$-amylase activity at their optimal temperature and $\mathrm{pH}$ is shown in Fig. 4. The result shows the basic kinetic characteristic and the expected Michealis-Mentens curve. The present observation indicates that $\alpha$-amylase from these cereals hydrolyse starch according to the normal enzyme catalysed reactions.

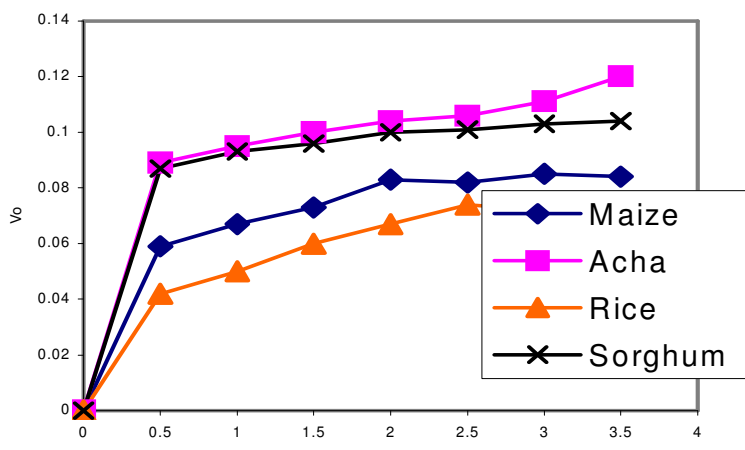

[s]

Fig 4: Substrate effect on alpha-amylase activity 


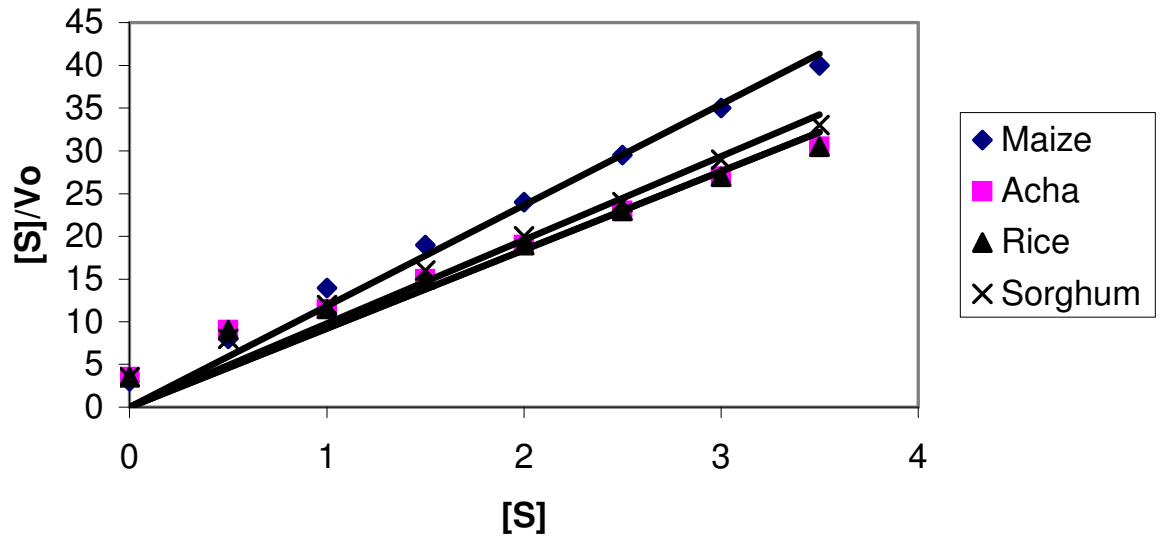

Fig. 5 Hanes plot of [S]/Vo vs [s]

From the Hanes plot (Fig. 5), $\mathrm{V}_{\mathrm{Max}}$ and $\mathrm{K}_{\mathrm{M}}$ were determined and presented in Table 2.

Table 2: Kinetic parameters of alpha-amylase from sprouting cereals

\begin{tabular}{|c|c|c|}
\hline Cereals & $\mathrm{V}_{\cdot \operatorname{Max}}\left(\mathrm{Sec}^{-1}\right)$ & $\mathrm{K}_{\mathrm{M}}(\mathrm{mg} /$ mins. $)$ \\
\hline Maize & $9.0 \times 10^{-2}$ & 0.23 \\
Acha & $12.5 \times 10^{-2}$ & 0.56 \\
Rice & $7.0 \times 10^{-2}$ & 0.29 \\
Sorghum & $12.5 \times 10^{-2}$ & 0.50 \\
\hline
\end{tabular}

The present observation shows that $\alpha$-amylase from acha and sorghum with high $\mathrm{V}_{\mathrm{Max}}$ and $\mathrm{K}_{\mathrm{M}}$ may be close alternatives. Sorghum $\alpha$-amylase has been shown to be the closest alternative to import $\alpha$-amylase for the Nigerian food industries $^{11,5}$ the present study shows that $\alpha$ amylase acha can also be as good as sorghum amylase and indeed could be a better source Acha has earlier been shown to have a higher $\alpha$ amylase yield (Fig.1).

Considering the amylase yield and kinetic parameters observed in the present work, it is possible to conclude that: The characteristics of $\alpha$-amylase from different sprouting Nigerian Cereals differ and so may have different levels of usefulness in the food industries. In terms of kinetic parameter, $\alpha$-amylase from acha and sorghum are quite related. Acha may be a better source for amylase production and can be a substitute for sorghum $\alpha$-amylase in industrial processing

\section{REFERENCE}

1. Vihinan, M. and Mantsala, P. (1989) Microbial amylolytic enzymes, CRC Rev. Biochem. Mol. Bid. 24:329-418

2. Takaku, H. (1988) Anomalously linked Oligosaccharides mixture, in Handbook of amylase and related enzymes: their sources, isolation methods, properties and application (Amylase research Society of Japan) pp 215-217 Pergamon press, New York.

3. Okafor, N, Aniche, G. and Adewoyin (1998) Preliminary studies of larger beer brewing from corn. Journal of food and agriculture 2:33-37

4. Palmer, G.H. (1989) Cereal Science Technology. Aberdeen University Press UK. Pp 147-148.

5. Shambe, T., Voncir, N. and Gambo, E. (1989) Enzyme and acid hydrolysis of malted millet (Peminsetun tyhoides) and sorghum (Sorghum bicolour). Journal of the Institute of Brewing 95:13-16.

6. Vontong, X. and Vonone, R. (1976) Training manual for Rice production institute pp 6-15

7. Kang G-J., Mo-jeong, K., Jeon-Weon, K. and Kwanhwa P. (1997) Immoblization of thermostable Maltogenic amylase from Bacillus Stearothermophilus for continuous production of branched oligosaccharide. $J$. Agric. Food Chem. 45:4168-4172. 
8. Olatunji, F and Ene, E. (1982) Mechanisms and Kinetics of bacterial $\alpha$-amylase hydrolysis of starch. Proceedings of $12^{\text {th }}$ Annual Conference of Nig. Soc. of Chemicals Engineers Lagos. Pp 307-317.

9. Francis, O. and Folorunsho, A. (1986) Effect of temperature and $\mathrm{pH}$ on the kinetics of activity of $\alpha$-amylase from a Garifermenting bacterium, Bacillus subtilis. $J$. Nig. Soc. Chem. Eng 5:17-20

10. Alli, A.I., Ogbonna, C.I. and Rahman, A.T.M.F. (1998) Hydrolysis of certain Nigerian cereal starches using crude fungal amylase. Nig. J. Biotech. 9:24-36

11. Solomon, B. O., Layothan, S. K., and Olatunji, S. (1987) Development of malt for the Nigerian Brewing Industries, Malting of Grain sorghum. J. Nig. Soc. Chem. Eng. B (1): 60-64. 